\title{
Optimalisasi Kesenian Tradisional Bernuansa Islami sebagai Salah Satu Destinasi Wisata Syariah di Madura
}

\author{
Firman Setiawan ${ }^{1}$, Nur Halimah ${ }^{2}$ \\ Lecturerst of Islamic Economics, Trunojoyo University of Madura ${ }^{1}$ \\ Student of Islamic Economics, Trunojoyo University of Madura ${ }^{2}$ \\ firman.setiawan@trunojoyo.ac.id ${ }^{1}$, nur.halimah12372@yahoo.com ${ }^{2}$
}

DOI: https://doi.org/10.21107/dinar.v5i1.5125

\section{Abstrak}

Pada zaman dabulu sebelum adanya perkembangan teknologi yang pesat, kesenian tradisional merupakan salah satu biburan yang paling diminati dan dinantikan oleh masyarakat Madura. Pertunjukan kesenian ini umumnya di tampilkan pada perayaan hari besar atau perayaan adat setempat. Islam sebagai agama mayoritas yang dianut oleh penduduk Madura turut mempengarubi kesenian tradisional tersebut. Banyak kesenian tradisional yang mengandung unsur-unsur Islami di dalamnya yang mencerminkan keseharian penduduk. Madura.

Fokus penelitian ini adalah bagaiamana meningkatkan minat masyarakat terhadap kesenian tradisional Madura. Metode penelitian yang diguanakamn dalam artikel ini dengan pendekatan kualitatif dengan jenis penelitian studi literatur. Metode pengumpulan data yang digunakan dalam penelitian ini menggunakan teknik triangulasi teori (Theory Triangulation) dengan analisanya menggunakan teknik analisis data deskriptif kualitatif.

Hasil penelitian ini menunjuk.kan bahwa optimalisasi kesenian tradisional bernuansa Islami tidak banya untuk menarik minat generasi muda akan seni itu sendiri. Namun bal ini juga dapat dijadikan sebagai salah satu upaya peningkatan ekonomi masyarakat setempat. Salah satu langkah yang dapat diambil adalah dengan menjadikan kesenian tradisional sebagai salah satu destinasi pariwisata Syariah mengingat pulau Madura sendiri berpotensi besar dalam pengembangan wisata budaya yang bernuansa Islami.

Kata Kunci : Kesenian Tradisional, Pariwisata Syariah 


\section{Pendahuluan}

Sebagai negara dengan jumlah suku bangsa yang beragam Indonesia menjadi Negara yang kaya akan kesenian dan budaya yang memiliki keunikan dan kekhasan tersendiri dan berbeda di setiap daerahnya. Kesenian sendiri, merupakan suatu karya yang bersumber dari ide,lalu berkembang menjadi suatu konsep yang dituangkan di suatu medium (Suranto Aw, 2010: 56).

Pada zaman dahulu sebelum adanya perkembangan teknologi yang pesat, kesenian tradisional merupakan salah satu hiburan yang paling diminati dan dinantikan oleh masyarakat setiap harinya. Kesenian tradisional menjadi sarana bagi masyarakat khususnya masyarakat pedesaan untuk bercengkerama dan berbaur dengan masyarakat lainnya sembari melepas lelah setelah bekerja.

Pertunjukan kesenian ini umumnya di tampilkan pada perayaan hari besar atau perayaan adat setempat. Setiap daerah di Indonesia memiliki keunikan seni tersendiri yang berbeda dan menjadi ciri khas daerah tersebut.

Salah satu daerah dengan keunikan kesenian tradisionalnya adalah Madura. Pulau yang terletak di utara pulau Jawa ini terkenal akan sikap religius penduduknya. Islam sebagai agama mayoritas yang dianut oleh penduduk Madura turut mempengaruhi kesenian tradisional di wilayah ini. Banyak kesenian tradisional yang mengandung unsur-unsur Islami didalamnya yang mencerminkan keseharian penduduk Madura.

Unsur-unsur Islam yang mempengaruhi kesenian tradisional Madura ini salah satunya adalah kesenian dalam bentuk sastra yang disebut Babad Tanah Madura. Dalam karya sastra ini di jelaskan bagaimana awal mula Islam masuk ke pulau Madura hingga bagaimana Islam dapat mempengaruhi sendi-sendi kehidupan masyarakat Madura, termasuk bagaimana Islam mempengaruhi kesenian-kesenian tradisional dari wilayah tersebut (Made Astika Dkk, 2014: 101).

Kesenian tradisional ini tersebar diantara 4 kabupaten di pulau Madura antara lain kabupaten Bangkalan,Sampang,Pamekasan, dan Sumenep. Untuk perkembangan kesenian tradisional sendiri hal ini didominasi oleh kabupaten Sumenep. Kabupaten yang terletak di ujung pulau Madura ini sudah sejak lama terkenal akan kearifan lokalnya. Salah satu peninggalan bersejarahnya yang mengandung unsur-unsur kebudayaan Islam adalah peninggalan keraton Sumenep serta masih banyak lagi peninggalan budaya maupun kesenian tradisional di daerah ini.

Namun seiring dengan perkembangan zaman kesenian tradisional Madura perlahan mulai ditinggalkan oleh peminatnya. Umumnya saat ini penggemar kesenian tradisional ini hanya terdiri dari orang-orang tua saja. Padahal jika di tinjau lebih jauh lagi kesenian tradisional ini mempunyai nilai-nilai norma kebaikan yang disampaikan secara halus. 


\section{Miara}

Surnal \& konomi \& Q Xuangan Qslam

https://journal.trunojoyo.ac.id/dinar/index

DOI: https://doi.org/10.21107/dinar
Dinar. Vol 6, No 2: Agustus 2019. 32-45

ISSN: 2460-9889 (Cetak)

ISSN: 2580-3565 (Online)

Untuk mengatasi hal tersebut maka diperlukan sebuah upaya agar kesenian-kesenian tradisional yang bernuansa islami ini kembali diminati oleh masyarakat, terutama generasi. Salah satu upaya yang bisa dilakukan yaitu dengan menjadikan kesenian tradisional sebagai salah satu destinasi pariwisata.

Jika optimalisasi kesenian tradisional yang bernuansa islami sebagai destinasi pariwisata ini berhasil dilakukan, maka dampaknya tentu tidak hanya dapat menarik minat generasi muda akan seni itu sendiri,tetapi juga dapat menjadi daya dorong untuk peningkatan ekonomi masyarakat setempat.

\section{Tinjauan Pustaka}

\section{Pengertian Kesenian}

Kesenian merupakan unsur pengikat yang mempersatukan pedoman-pedoman bertindak yang berbeda menjadi suatu desain yang utuh, menyeluruh, dan operasional, serta dapat diterima sebagai sesuatu yang bernilai (Bahari, 2014: 45).

Kesenian merupakan sebuah kebutuhan estetika dalam menikmati keindahan, apresiasi dan mengungkapkan perasan yang muncul disebabkan sifat dasar manusia. Sehingga dalam memenuhi kebutuhan estetika ini kesenian menjadi bagian integral yang tak terpisahkan dengan kebudayaan serta sistem simbol sebagai pedoman bagi pemenuhan kebutuhan integratif (Bahari, 2014: 46).

1) Macam-macam Kesenian

a. Berdasarkan Jenisnya

a) Seni rupa.

Seni rupa di Indonesia pada dasarnya telah dimulai sejak masa raden saleh pada pertengahan abad ke 19. Seni Rupa modern yang di perkenalkan masih bermuara pada suasana hidup masyarakat waktu itu, dimana warna dasarnya adalah kehidupan keraton. Namun kemudian aktivitas seni rupa modern Indonesia sempat meredup setengah abad lamanya sebelum munculnya pelukis-pelukis pasca Raden Saleh seperti Abdullah SurioSubroto, mas Piringadi, S Soedjono, Hendra Gunawan, OmarBasmallahdan Affandi.

Di lingkungan golongan menengah sendiri mulai muncul kebutuhan terhadap seni modern ketika pada awalnya mereka mulai belajar mengapresiasi seni modern dalam masa pendidikan Belandanya. Mereka membaca bacaan-bacaan Sastra Barat, menikmati ilustrasi-ilustrasi bukunya yang digambar dengan cara yang berbeda dengan ilustrasiilustrasi yang ada pada buku-buku daerah yang ada pada saat itu. Namun yang perlu diingatkan bahwa tingkat keterpelajaran mereka pada saat itu belum terlalu tinggi sehingga pada dasarnya fungsi seni modern bagi mereka masih terbatas pada mereka pemenuhan seni hiburan ringan dan tanpa banyak merangsang pemikiran intelektual.

b) Seni Musik 


\section{Miara}

Eurnal \& konomi \& Qeuangan @slam

https://journal.trunojoyo.ac.id/dinar/index

DOI: https://doi.org/10.21107/dinar
Dinar. Vol 6, No 2: Agustus 2019. 32-45

ISSN: 2460-9889 (Cetak)

ISSN: 2580-3565 (Online)

Budaya musik Indonesia yang terdapat di seluruh nusantara berdasarkan kontes teori merupakan kesenian musik yang mentradisi dengan dinamika produksi penciptaan yang relatif rendah, akrab dengan improvisasi yang ditangani secara amatir, dan merupakan komposisi atematis. Ia ditopang tradisi lisan yang menjurus ke proses pemiskinan dan mengalami segmentasi etnik dan dibingkai dengan bahasa-bahasa daerah, hanya berguna untuk menciptakan suasana-suasana dalam konteks kolektifitisme dan tidak menjadi sarana pendidikan umum demi presisi, imaginasi, kreatifitas dan kecerdasan.

Dalam perjalanan panjang musik di Indonesia mengalami mozaik dengan masuknya solmisasilagu, diatonik dalam tradisi rakat melalui penggunaan instrumen musik seperti gitar, ukulele, cello, biola, dan fluite. Pada tahun 1919 di Batavia masuk aliran baru yang di sebut gambus yang diperkenalkan oleh Mubarok bersama grupnya al-Khalifah.

c) Seni Tari

Bila dibandingkan dengan seni rupa dan seni musik, maka seni tari Indonesia menampakkan kelambanan dalam perkembangannya, bukan karena keterlambatan kelahirannya namun lebih pada belum adanya proses transmisi nilai yang mantap, proses generasi tidak baik.

Tari kontemporer baru dipelopori kelahirannya semenjak periode BagongKassudiardjodan Wisnu Wardana pada tahun 1960-an baru kemudian dilanjutkan oleh generasi-generasi selanjutnya.Proses regenerasinya sendiri hanya berlangsung secara mantap pada padepokan BagongKasudiardjo. Namun, sangat disayangkan bahwa semua anak didik Bagongjustru bukan tertarik pada pengembangan dan penggalian nilai seni tari modern atau kontemporer Indonesia yang lebih membumi seperti apa yang telah dilakukan oleh SardonoW Kususmo. Mereka justru terpanggil untuk menekuni penciptaan tari pesanan dari dan untuk acara resmi pemerintah dalam batasan ideologi kesenian yang sempit.

b. Berdasarkan Karakteristiknya.

a) Kesenian Tradisional

Kesenian tradisional adalah bentuk hasil karya yang mengandung nilai estetika dan berpegang teguh pada tradisi. Dengan kata lain pengertian seni tradisional adalah bentuk seni yang berpedoman pada aturan atau kaidah secara turun-temurun. Seni tradisional ini merupakan suatu unsur yang menjadi bagian dari hidup masyarakat yang tinggal di daerah tertentu. Seni tradisional pada setiap daerah berbeda terbatas pada lingkungan dan budaya yang menunjangnya.

Kesenian tradisional ini merupakan pencerminan dari suatu budaya dan hal yang berpengaruh pada suatu daerah tersebut. Seni tradisional sendiri merupakan bagian dari kehidupan masyarakat yang menjadi pembeda seni suatu tempat dengan tempat lain. 
Seni tradisional ini diciptakan berdasarkan filosofi yang yang ada dan aktivitas kebudayaan yang ada di daerah tertentu. Seni tradisional ini bersifat statis, tidak terdapat unsur kreatif sebagai penciptaan baru.

b) Kesenian Modern

Seni modern merupakan karya seni yang dihasilkan dalam periode terentang antara 1860-an hingga 1970-an dengan menggunakan gaya dan filosofi seni yang dihasilkan pada masa itu. Pada dasarnya dunia seni modern berada pada struktur budaya sosial yang lebih luas sebagai hasil perkembangan dunia dunia selama akhir abad ke-19 dan awal abad ke20. Seniman-seniman modern umumnya bereksperimen dengan gaya baru yang unik dan dengan menghasilkan ide ide segar mengenai fungsi dari seni dan material-material yang digunakan. Mereka cenderung menciptakan karya seni yang dihasilkan dari perasaan yang dalam dan inspirasi inspirasi yang kreatif pada umumnya. Mereka cenderung menciptakan karya seni yang dihasilkan yang dihasilkan dari perasaan yang dalam dan inspirasi-inspirasi yang kreatif pada umumnya.

Bahkan ketika karya mereka sepertinya tidak memiliki tujuan atau makna apapun pada umumnya, kenyataannya hasil karya tersebut memiliki makna sendiri tergantung apa yang tengah terjadi dalam situasi dan kondisi pada masa tertentu dan sesuai dengan intelektual masyarakat yang lebih luas.

\section{Pengertian Pariwisata}

Istilah tourismpariwisata muncul di masyarakat abad ke-18, khususnya sesudah Revolusi Industri di Inggris Istilah Pariwisata berasal dari dilaksanakannya kegiatan wisata atau tour yaitu sesuatu aktivitas perubahan tempat tinggal sementara seseorang. Istilah pariwisata diperkenalkan pertama kali di Indonesia pada saat Musyawarah Nasional Yayasan TourismeIndenesia ke-II atau usul dari presiden pertama Ir. Soekarno dan akhirnya pada 1961 istilah dipakai resmi untuk menggantikan istilah tourisme (Muljadi \& Warman, 2016: 07).

Pariwisata merupakan keseluruhan hubungan dan gejala-gejala yang timbul dari adanya orang asing dimana perjalanannya tidak untuk bertempat tinggal menetapkan dan tidak ada hubungan dengan kegiatan untuk mencari nafkah (Muljadi \& Warman, 2016: 09).

Menurut Undang-Undang Republik Indonesia Nomor 9 Tahun 1990 tentang Kepariwisataan, bahwa pengertian pariwisata adalah segala sesuatu yang berhubungan dengan wisata termasuk pengusahaan objek dan daya tarik wisata serta usaha-usaha yang tertarik di bidang ini.

Sedangkan dalam Undang-Undang Republik Indonesia Nomor 10 Tahun 2009 tentang kepariwisataan, memberikan pengertian bahwa pariwisata adalah berbagai macam kegiatan wisata dan didukung berbagai fasilitas serta layanan yang disediakan oleh masyarakat, pengusaha, pemerintah, dan pemerintah daerah. 


\section{Minar}

Eurnal \&konomi \& Q Quangan बslam

https://journal.trunojoyo.ac.id/dinar/index

DOI: https://doi.org/10.21107/dinar
Dinar. Vol 6, No 2: Agustus 2019. 32-45

ISSN: 2460-9889 (Cetak)

ISSN: 2580-3565 (Online)

Sedangkan pengertian pariwisata syariah bisa didefinisikan sebagai suatu kegiatan wisata yang didukung dengan berbagai fasilitas serta layanan yang sesuai dengan prinsip Syariah. Adapun yang dimaksud dengan prinsip syariah adalah prinsip hukum Islam terkait berbagai kegiatan pariwisata berdasarkan fatwa yang dikeluarkan oleh lembaga yang berwenang. Di Indonesia lembaga dimaksud adalah Dewan Syariah Nasional Majelis Ulama Indonesia (DSN-MUI).

2) Macam-macam Pariwisata

Terdapat berbagai jenis pariwisata yang dikelompokkan berdasarkan tujuan atau motif seseorang atau kelompok yang melakukan perjalanan wisata berikut jenis-jenis pariwisata :

a. Pariwisata untuk menikmati perjalanan (Pleasure Tourism). Jenis pariwisata ini dilakukan oleh orang-orang yang meninggalkan tempat tinggalnya untuk berlibur, untukmenikmatikeindahan alam, atau untukmendapatkan ketenangan dan kedamaian di daerah kota.

b. Pariwisata untuk Rekreasi (Recreation Tourism). Jenis pariwisata ini dilakukan oleh orangorang yang menghendaki pemanfaat hari liburnya untuk istirahan dan menyegarkan kembali kesegaran jasmani dan rohani akibat terlalu banyak bekerja.

c. Pariwisata untuk Kebudayaan (Cultural Tourism). Jenis pariwisata ini dilakukan karena adanya keinginan untuk mempelajari adat istiadat, kelembagaan dan cara hidup rakyat daerah lain selain itu untuk mengunjungi momentum bersejarah,peninggalan peradaban masa lalu, pusat-pusat kesenian, pusat-pusat keagamaan, atau untuk ikut serta dalam festival-festival seni musik, teater, tarian rakyat, dll.

\section{3) Destinasi Wisata}

Menurut Kamus Besar Bahasa Indonesia, Destinasi merupakan tempat atau tujuan,di mana inti dari produk pariwisata adalah destinasi wisata yang menjadi daya tarik utama dalam perkembangan industri pariwisata dan mempunyai keunggulan dan ciri khas, baik secara geografis maupun budaya sehingga dapat menarik wisatawan untuk mengunjungi dan menikmatinya.

Destinasi Wisata merupakan daerah yang ideal untuk mengevaluasi jaringan inovasi antar perusahaan karena dua alasan pertama organisasi di destinasi pariwisata sangat berjenjang sampai pada tingkat tujuan. dapat dipahami sebagai "kelompok pemasok independen yang digabungkan secara longgar yang terkait untuk memberikan keseluruhan produk, selama bertahun-tahun, destinasi telah semakin berjenjang sebagai respons terhadap harapan wisatawan akan sebuah pengalaman menyeluruh daripada serangkaian pertukaran terpisah (Prasetyo \& Arifin, 2018: 04).

4) Cara Mengoptimalisasi Pariwisata 


\section{Miara}

Eurnal \& konomi \& Qeuangan @slam

https://journal.trunojoyo.ac.id/dinar/index

DOI: https://doi.org/10.21107/dinar
Dinar. Vol 6, No 2: Agustus 2019. 32-45

ISSN: 2460-9889 (Cetak)

ISSN: 2580-3565 (Online)

Menurut Muljadi \& Warman (2016) salah satu pengoptimalan pariwisata di suatu daerah agar dapat dikenal oleh masyarakat luas antara lain dapat menggunakan beberapa cara antara lain:

1. Pengadaan Perencanaan Paket Wisata

Paket wisata sendiri dapat diartikan sebagai suatu program perjalanan wisata dengan beberapa tujuan wisata yang tersusun dari berbagai fasilitas jasa perjalanan tertentu yang tersusun berdasarkan jadwal acara yang telah ditetapkan.

Paket wisata merupakan produk pariwisata yang direncanakan oleh seorang petugas perencana pariwisata atau tourplanner. Seorang petugas perencanaan harus menguasai dan paham tentang berbagai aspek yang berkaitan dengan kegiatan wisata, salah satunya adalah dengan menyediakan fasilitas pendukung perjalanan yang dapat memberikan pemenuhan kebutuhan dalam perjalanan wisata para wisatawan saat berkunjung. Segala sesuatu itu harus tersedia pada daerah tujuan sebagai salah satu daya tarik wisatawan dan pertimbangan mereka ketika hendak berkunjung. Komponen-komponen paket pariwisata yang dapat dirancang meliputi: Jasa transportasi baik darat, laut, maupun udara, Jasa penginapan, Jasa penyajian makanan dan minuman, Jasa daa tarik wisata, rekreasi, seni budaya dan Jasa pemandu wisata Paket wisata dapat dipasarkan secara langsung oleh biro perjalanan wisata itu sendiri atau melalui perantara, yaitu agen perjalanan wisata dengan memberikan imbalan berupa komisi penjualan paket wisata yang terjual sesuai kesepakatan oleh kedua belah pihak.

2. Pembentukan Desa Wisata

Desa wisata dapat menjadi salah satu daya tarik wisatawan lokal maupun mancanegara.

Desa wisata ini dapat berupa desa adat ataupun desa Seni dan desa sentra penghasil kerajinan tangan.

Pembentukan desa wisata dapat dijadikan sebagai objek cultural Tourism yaitu salah satu jenis pariwisata yang disebabkan adanya daya tarik seni dan budaya di suatu daerah atau tempat seperti, peninggalan nenek moyang, benda-benda kuno, kesenian tradisional, serta upacara-upacara Adat yang khas dari wilayah tersebut contohnya, seperti wisata upaya ngaben di Bali, Pemakaman raja-raja di Toraja,

Pembentukan desa wisata ini juga dapat dijadikan sebagai sarana wisata edukasi yang bertujuan untuk menambah pengetahuan dan mengadakan penelitian dan mempelajari dari dekat kebudayaan setempat melalui objek wisata yang dikunjungi.

3. Pembentukan Jasa Informasi Kepariwisataan

Pembentukan jasa informasi kepariwisataan ini menjadi sarana penyedia informasi mengenai objek dan daya tarik wisata dari suatu wilayah yang dipromosikan juga 


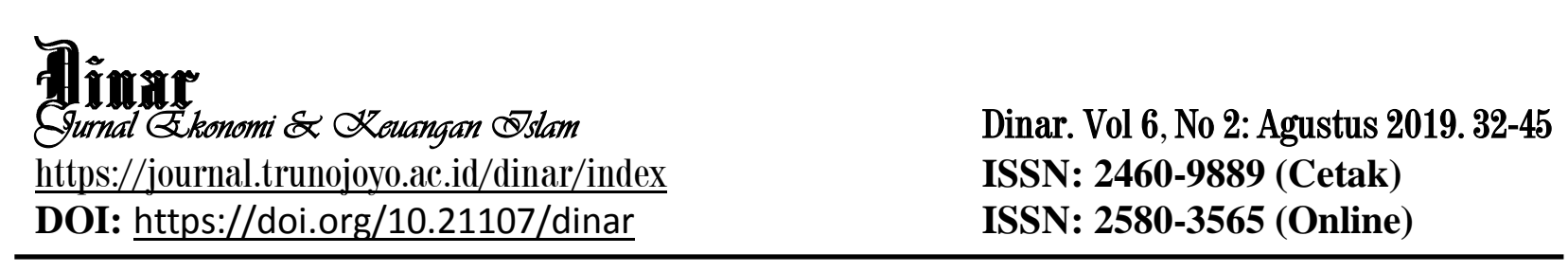

menyediakan informasi-informasi lain yang diperlukan oleh wisatawan yang akan berkunjung ke daerah wisata tersebut.

Penyebaran informasi tentang usaha pariwisata ataupun tentang tempat-tempat wisata yang menarik di suatu daerah dapat melalui media cetak, media elektronik ataupun media komunikasi lainnya.

Jasa informasi kepariwisataan ini dapat berisi tentang informasi akomodasi, restoran, penerbangan, angkutan darat, angkutan laut, dan jasa layanan pemesanan. Selain itu, penyedia jasa informasi kepariwisataan bertanggung jawab atas kebenaran informasi kepariwisataan yang disediakan.

Menurut Salah satu pengoptimalan pariwisata di suatu daerah agar dapat dikenal oleh masyarakat luas antara lain dapat menggunakan beberapa cara antara lain: ${ }^{1}$

4. Pengadaan Perencanaan Paket Wisata

Paket wisata sendiri dapat diartikan sebagai suatu program perjalanan wisata dengan beberapa tujuan wisata yang tersusun dari berbagai fasilitas jasa perjalanan tertentu yang tersusun berdasarkan jadwal acara yang telah ditetapkan.

Paket wisata merupakan produk pariwisata yang direncanakan oleh seorang petugas perencana pariwisata atau tourplanner. Seorang petugas perencanaan harus menguasai dan paham tentang berbagai aspek yang berkaitan dengan kegiatan wisata, salah satunya adalah dengan menyediakan fasilitas pendukung perjalanan yang dapat memberikan pemenuhan kebutuhan dalam perjalanan wisata para wisatawan saat berkunjung. Segala sesuatu itu harus tersedia pada daerah tujuan sebagai salah satu daya tarik wisatawan dan pertimbangan mereka ketika hendak berkunjung. Komponen-komponen paket pariwisata yang dapat dirancang Muljadi \& Warman, (2016: 157) meliputi Jasa transportasi baik darat, laut, maupun udara, Jasa penginapan, Jasa penyajian makanan dan minuman, Jasa daya tarik wisata, rekreasi, seni budaya dan Jasa pemandu wisata

Paket wisata dapat dipasarkan secara langsung oleh biro perjalanan wisata itu sendiri atau melalui perantara, yaitu agen perjalanan wisata dengan memberikan imbalan berupa komisi penjualan paket wisata yang terjual sesuai kesepakatan oleh kedua belah pihak.

5. Pembentukan Desa Wisata

Desa wisata dapat menjadi salah satu daya tarik wisatawan lokal maupun mancanegara. Desa wisata ini dapat berupa desa adat ataupun desa Seni dan desa sentra penghasil kerajinan tangan.

\footnotetext{
${ }^{1}$ Muljadi dan Andri Warman, Kepariwisataan dan Perjalanan..,157
} 


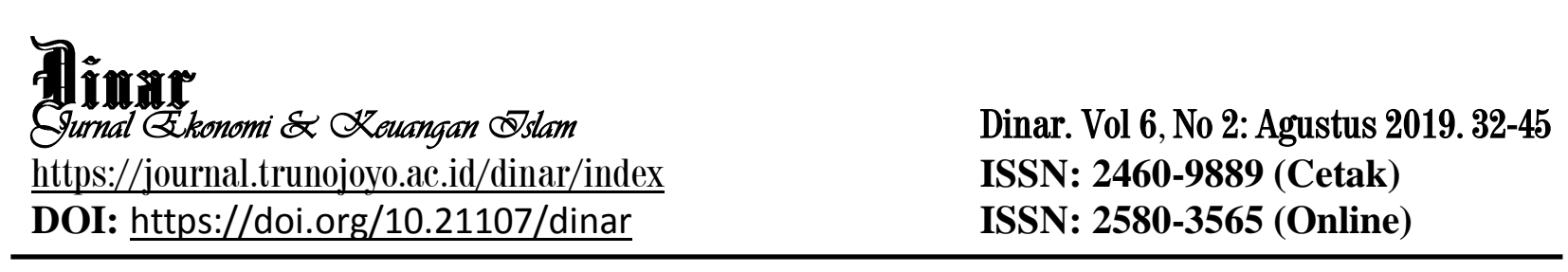

Pembentukan desa wisata dapat dijadikan sebagai objek cultural Tourism yaitu salah satu jenis pariwisata yang disebabkan adanya daya tarik seni dan budaya di suatu daerah atau tempat seperti, peninggalan nenek moyang, benda-benda kuno, kesenian tradisional, serta upacara-upacara Adat yang khas dari wilayah tersebut contohnya, seperti wisata upaya ngaben di Bali, Pemakaman raja-raja di Toraja,

Pembentukan desa wisata ini juga dapat dijadikan sebagai sarana wisata edukasi yang bertujuan untuk menambah pengetahuan dan mengadakan penelitian dan mempelajari dari dekat kebudayaan setempat melalui objek wisata yang dikunjungi.

6. Pembentukan Jasa Informasi Kepariwisataan

Pembentukan jasa informasi kepariwisataan ini menjadi sarana penyedia informasi mengenai objek dan daya tarik wisata dari suatu wilayah yang dipromosikan juga menyediakan informasi-informasi lain yang diperlukan oleh wisatawan yang akan berkunjung ke daerah wisata tersebut.

Penyebaran informasi tentang usaha pariwisata ataupun tentang tempat-tempat wisata yang menarik di suatu daerah dapat melalui media cetak, media elektronik ataupun media komunikasi lainnya.

Jasa informasi kepariwisataan ini dapat berisi tentang informasi akomodasi, restoran, penerbangan, angkutan darat, angkutan laut, dan jasa layanan pemesanan. Selain itu, penyedia jasa informasi kepariwisataan bertanggung jawab atas kebenaran informasi kepariwisataan yang disediakan.

\section{Metode Penelitian}

\section{Jenis Penelitian}

Jenis penelitian dalam penelitian ini adalah kualitatif dengan pendekatan studi literatur dengan sumber data yaitu data sekunder yang diperoleh dari penelitian-penelitian terdahulu, dan sumber referensi lainnya. Studi literatur adalah cara yang dipakai untuk menghimpun data-data atau sumber-sumber yang berhubungan dengan topik yang diangkat dalam suatu penelitian yang didapat dari berbagai sumber, jurnal, buku dokumentasi, internet dan pustaka.Penelitian ini memberikan gambaran secara diskriptif tentang potensi wisata yang ada di Madura menjadi wisata syariah dengan mengembangkan kesenian tradisional yang benuansa islami itu perlu dioptimalkan guna mengatasi masalah ekonomi khsusnya kemiskinan, sehingga pertumbuhan ekonomi akan meningkat, lebih lanjut pembangunan akan berjalan dengan baik.

\section{Jenis Data}

Jenis data dalam penelitian ini menggunakan data sekunder. Data sekunder adalah sumber data yang tidak langsung memberikan data kepada pengumpul data. Data sekunder ini merupakan data yang sifatnya mendukung keperluan data primer seperti buku- 
buku, penelitian-penelitian sebelunya dan berbagai sumber bacaan yang berkaitan dengan zakat dan pengentasan kemiskinan.

\section{Metode Pengumpulan Data}

Metode pengumpulan data yang digunakan dalam penelitian ini menggunakan teknik triangulasi teori (Theory Triangulation). Data atau informasi dari satu pihak diperiksa kebenarannya dengan cara memperoleh informasi dari sumber lain. Tujuannya adalah membandingkan informasi tentang hal yang sama yang diperoleh dari berbagai referensi dan literatur agar ada jaminan tingkat kepercayaannya.

\section{Metode Analisis Data}

Metode analisis data yaitu teknik analisis data deskriptif kualitatif yaitu dengan datadata yang diperoleh dari tinjauan literatur serta website terkait disusun menjadi sebuah faktafakta yang aktual untuk kemudian dilakukan pembahasan.

\section{Pembahasan}

\section{Kesenian Tradisional Madura}

Kesenian Tradisional merupakan bagian dari kebudayaan dasar yang menyokong adanya kebudayaan yang hidup dan berkembang dalam kehidupan masyarakat dan menjadi salah satu wahana untuk menunjukkan jati diri dalam kehidupan dalam berbagai aneka suku bangsa di Indonesia (Hendri Purnomo, 2009: 85).

Secara garis besar seni tradisional Madura dapat diklasifikasi menjadi empat kelompok. Dari masing-masing kelompok mempunyai tujuan maupun fungsi yang berbeda. Bentuk kesenian tersebut menurut Irmawati (2004: 56) berupa: Seni musik/seni suara, yaitu Tembang Macapat,Musik Saronen, Musik Ghul-Ghul, dan lain-lain. Seni tari/gerak, yaitu Tari Duplang, Tari Muang Sangkal, Tari Pecut, Tari Samper Nyecceng, dan lain-lain. Upacara Ritual, yaitu Sandhur, Adat Nyadhar, Petik Laut. Pentas Seni Pertunjukan, yaitu Kerapan Sapi, Sapi Sono, Pencak Silat Ghul-Ghul, Sintung, Topeng Dalang, dan lain-lain.

Kesenian tradisional Madura di setiap Kabupaten itu berbeda-beda. Namun yang paling banyak bertempat di Kabupaten Sumenep karena disana terdapat peninggalanpeninggalan Keraton Batuputih.

\section{Kesenian Tradisional Madura Benuansa Islami}

Kesenian tradisional bernuansa Islami merupakan kesenian yang banyak mengandung nilai-nilai agama dan berbagai nilai-nilai yang sangat bermanfaat sehari-haribaik dalam penampilanmaupun dalam syair-syair yang mereka bawakan dari mulai busana yang mereka kenakan yaitu busana muslim hingga pada syair-syair yang pada umumnya merupakan pujianpujian terhadap Rasulullah SAW (Hendri Purnomo, 2009: 68). 
Berbagai bentuk kesenian tradisional Madura dapat dijadikan sebagai media untuk menanamkan nilai-nilai keagamaan seperti jenis instrumen musik yang mampu menghasilkan jenis irama riang dan dinamis, sehingga sangat cocok untuk masyarakat Madura yang yang terkenal berwatak dan berkarakter keras, terbuka, hangat, dan polos dan melalui media ini para da'i memasukkan ajaran berupa ajakan untuk memperbaiki moral, membentuk kepribadian yang baik, bentuk kesenian yang ada di Madura dipakai sebagai Ukhuwah Islamiah dan menyambung tali silaturahmi sehingga membentuk kesenian yang bernafaskan Islami.

Kesenian tradisional Madura yang bernuansa Islam itu sangat beragam diantaranya yaitu: tarian hadrah, gambus, tarian sholawat atau rampok jidor, adat Nyadhar, dan Tembang macapat/macopat.

Tarian Hadra merupakan kesenian asal Sumenep yang dilakukan beberapa orang dengan diiringi musik salawat.Biasanya tarianhadra ini dilakukan di dalam acara perkumpulan antar warga dengan tujuan untuk menghibur masyarakat. Gambus merupakan kesenian yang hampir sama dengan hadra terdapat tarian dan diiringi musik shalawat. Bedanya, musik gambus lebih modern dan alat musiknya juga berbeda dengan hadra.

Tarian sholawat atau rampok jidor adalah tarian yang dimiliki oleh masyarakat Madura ini merupakan tarian yang menggambarkan karakter orang Madura yang sangat relegius dan biasanya dilakukan di daerahBangkalan dan sekitarnya. Seluruh gerak dan alunan irama nyanyian yang megiringi tari ini mengungkapkan sikap dan ekspresi sebuah pujianpujian, do'a dan dzikir kepada Allah SW'T.

Adat nyadhar (nyadar) adalah tradisi yang dilakukan oleh masyarakat petani garam di kabupaten Sumenep. Tradisi ini dilaksanakan dengan berziarah ke makam leluhur yang disebut dengan bujuk (makam) Gubang sambil bersedekah makanan. Tradisi nyadhar ini dilakukan tiga kali dalam setahun yang dilaksanakan secara berturut-turut dengan waktu berselang satu bulan. Ada tiga syarat yang harus dipatuhi dalam pelaksanaan tradisi nyadhar ini, yaitu tidak boleh dilaksanakan sebelum tanggal 12 maulid, selamatan yang dilakukan tidak boleh lebih besar dari selamatan maulid nabi, dan peserta yang mengikuti upacara nyadhar harus merayakan maulid nabi terlebih dahulu.

Tembang macapat/macopat pada awalnya, tembang macapat/macopat digunakan sebagai media untuk melantunkan puji-pujian kepada Allah SWT yang biasanya dilantunkan sebelum melaksanakan shalat lima waktu. Namun tembang ini kemudian juga digunakan untuk ajakan kepada kebaikan-kebaikan, seperti mencintai ilmu, memperbaiki akhlak dan mencari kebenaran.

Macapat Madura dan macapat Jawa memiliki banyak kesamaan. Hal ini dikarenakan keduanya yang memang berasal dari satu sumber. Keduanya diikat oleh suatu aturan tembang, yaitu jumlah gatra (padde) dari masing-masing tembang berbeda, mengikuti aturan 
guru lagu dan guru wilangan yang sama. Adapun perbedaannya terletak pada syair yang dinyanyikan, pada tembang Macapat Jawa syair mengikuti aturan not balok atau angka, sedangkan di Madura lebih mengutamakan cengkok atau lagu.

Jenis tembang Macapat Madura dikategorikan dalam tiga jenis, yaitu tembang raja, tembang tengahan dan tembang Macopat atau tembang kene'. Tembang Macopat atau tembang kene' ada 11 tembang, yaitu Salanget (Kinanti), Pucung, Mejil (Medjil), Maskumambang, Durma, Kasmaran (Asmaradana), Pangkor, Senom (Sinom), Artate' (Dandanggula), Megattro (Megatruh), dan Gambuh.

Kesenian Madura yang bernuansa islami sangat beragam dan hampir sama di setiap daerahnya.Yang membedakan adalah pada penamaan dari kesenian tersebut. Namun kesenian tersebut tidak begitu dikenal oleh masyarakat luas dikarenakan sudah jarang ditampilkan di masyarakatnya sendiri.

\section{Optimalisasi Kesenian Tradisional Madura Bernuansa Islam Sebagai Destinasi Pariwisata}

Keanekaragaman kesenian tradisional Madura yang berisi nilai-nilai budaya yang tinggi dan nilai religius serta nilai persaudaraan yang seharusnya diperkenalkan kembali kepada generasi penerus atau pewaris dari kesenian tradisional. Namun karena adanya pengaruh global yang mengalir luas kepada generasi muda sehingga bentuk kesenian tradisional ini mulai memudar dimana yang seharusnya kekayaan budaya lokal merupakan aset yang mampu melindungi anak bangsa dan mempertahankan jati dirinya.

Oleh karena itu untuk mengantisipasi agar kesenian tradisional Madura ini tidak punah maka perlulah optimalisasi kesenian tradisional Madura sebagai destinasi wisata, sehingga kesenian-kesenian tradisional tersebut, terutama yang bernuansa islamidapat dilestarikan dan dikenalkan kepada generasi muda dan juga masyarakat luar Madura.

Sebagaimana yang telah dijelaskan sebelumnya, optimalisasi ini bisa dilakukan dengan beberapa cara sebagai berikut:

1) Pengadaan Perencanaan Paket Wisata. Paket wisata bisa direncanakan dan ditawarkan oleh petugas perencana pariwisata atau tourplanner. Paket perjalanan wisata ini bisa dikemas dengan wisata religi, sejarah dan budaya, mulai dari kabupaten Bangkalan sampai Sumenep.

2) Pembentukan Desa Wisata. Beberapa daerah di Madura saat ini memang sedang dibidik oleh BPWS untuk dijadikan sebagai desa wisata. Hal ini terlihat dari kegiatan-kegiatan yang dilakukan oleh BPWS, seperti memberikan pelatihan pengambangan desa wisata untuk masyarakat. Hanya saja hingga saat ini, desa wisata di Madura masih belum terwujud. Oleh karena itu barangkali perlu ada percepatan dan kerja sama yang baik antara 


\section{Miar}

Eurnal \& konomi \& Qeuangan @slam

https://journal.trunojoyo.ac.id/dinar/index

DOI: https://doi.org/10.21107/dinar
Dinar. Vol 6, No 2: Agustus 2019. 32-45

ISSN: 2460-9889 (Cetak)

ISSN: 2580-3565 (Online)

BPWS dan kepala-kepala daerah yang ada di Madura sehingga desa wisata ini bisa segera diwujudkan.

3) Pembentukan Jasa Informasi Kepariwisataan. Pembentukan jasa informasi ini menjadi sangat penting mengingat kesenian tradisional Madura yang bernuansa islami ini mungkin tidak banyak dikenal oleh masyarakat, bahkan oleh masyarakat Madura sendiri. Pemberian informasi ini bisa dilakukan oleh pemerintah dengan bekerja sama dengan pihak-pihak yang mungkin bisa untuk terlibat, seperti perguruan tinggi, tokoh masyarakat dan komunitas. Universitas Trunojoyo Madura, misalnya, sudah memiliki media untuk pengenalan dan pemasaran destinasi wisata yang ada di Madura. Tinggal kemudian bagaimana ini bisa dimanfaatkan secara maksimal, sehingga yang dikenalkan dan dipasarkan tidak hanya destinasi wisata alam yang ada di Madura, tetapi juga kesenian tradisional yang bernuansa Islami.

\section{Kesimpulan}

Dengan mengoptimalkan kesenian tradisional Madura sebagai salah satu destinasi pariwisata budaya di pulau Madura dapat diharapkan kesenian tradisional dapat tetap eksis di tengah gempuran teknologi modern.kesenian tradisional ini diharapkan dapat dikenal luas oleh masyarakat tidak hanya dari golongan orang tua tapi juga dari golongan muda.

Destinasi pariwisata budaya ini dapat merangsang keinginan generasi muda untuk mempelajari adat istiadat, kelembagaan dan cara hidup rakyat daerah lain selain itu untuk mengunjungi momentum bersejarah, peninggalan peradaban masa lalu, pusat-pusat kesenian, pusat-pusat keagamaan, atau untukikut serta dalam festival-festival seni musik, teater, tarian rakyat, dan lain-lain.

Penyebaran informasi tentang usaha pariwisata budaya ini sendiri ataupun tentang tempat-tempat wisata yang menarik di suatu daerah dapat melalui media cetak, media elektronik ataupun media komunikasi lainnya. Jasa informasi kepariwisataan ini dapat berisi tentang informasi akomodasi, restoran, penerbangan, angkutan darat, angkutan laut, dan jasa layanan pemesanan. Selain itu, penyedia jasa informasi kepariwisataan bertanggung jawab atas kebenaran informasi kepariwisataan yang disediakan.

\section{Daftar Pustaka}

Bahari, N. (2014). Kritik Seni (Wacana Apresiasi dan Kreasi). Yogyakarta: Pustaka Pelajar.

Hendri Purnomo, dkk; (2009). Bibliografi Beranotasi :Hasil Penelitian Balai Pelestarian Sejarah dan Nilai Tradisional Tanjungpinang. Jakarta: Departemen kebudayaan dan pariwisata balai pelestarian sejarah dan nilai tradisional Tanjungpinang.

Irmawati, Rosida (2004). Berkelana Dengan Kesenian Tradisional Madura. Surabaya: SIC. 
Made Astika Dkk. (2014). Sastra Lisan Teori Dan Penerapan. Yogyakarta: Graha Ilmu.

Muljadi, \& Warman, A. (2016). Kepariwisataan dan Perjalanan. Jakarta: Rajawali Pers.

Prasetyo, A., \& Arifin, M. Z. (2018). Pengelolaan Destinasi Wisata Yang Berkelanjutan Dengan Sistem Indikator Pariwisata. Jakarta: Indocamp.

Suranto Aw. (2010). Komunikasi Social dan Budaya. Yogyakarta: Graha Ilmu.

UU Republik Indonesia Nomor 10 Tahun 2009

UU Republik Indonesia Nomor 9 Tahun 1990 